\title{
An Empirical Analysis of The Impact of Islamic Banking on Real Output in Indonesia
}

\author{
Hadi Sasana \\ Universitas Diponegoro, Semarang, Indonesia \\ email: hadisasana@live.undip.ac.id
}

\section{Deni Ramdani}

Universitas Tidar, Magelang, Indonesia

email: deni.ramdani@untidar.ac.id

\section{Ivo Novitaningtyas \\ Universitas Tidar, Magelang, Indonesia \\ email: ivo.novitaningtyas@untidar.ac.id}

\begin{abstract}
The role and contribution of Islamic finance on economic growth in Indonesia has increased gradually and steadily. This is because the Islamic economy's universal and comprehensively basic principle is the primary foundation of Islamic banking. This research aimed to analyze the role of Islamic Banking on Indonesia's real sector during 2007.01 - 2016.04. This study used the Vector Error Correction Model (VECM) as a tool to analyze secondary data. The result showed that in Indonesia, sharia deposit positively and significantly influenced actual output in the short term. In addition, in the long-term, sharia financing positively and significantly influenced actual output. Moreover, Granger Causality Test proved the occurrence of one-way causality between actual output and inflation. Thus, Islamic banking can encourage actual output in Indonesia. The results of this study become a consideration for stakeholders and policymakers to pay more attention to strategies and policies that support economic growth in Indonesia.
\end{abstract}

Keywords: Islamic Banking; Sharia Deposit; Sharia Financing; Inflation; GDP

\begin{abstract}
Abstrak: Perkembangan keuangan syariah di Indonesia semakin meningkat setiap tahunnya. Prinsip-prinsip dasar ekonomi syariah yang universal dan komprehensif merupakan landasan utama perbankan syariah. Tujuan penelitian ini untuk menginvestigasi peran perbankan syariah terhadap sektor riil di Indonesia selama periode 2007.01 - 2016.04. Penelitian ini menggunakan Vector Error Correction Model (VECM) sebagai alat untuk menganalisis data sekunder. Hasil penelitian menemukan bahwa dalam jangka pendek deposito syariah berpengaruh positif dan signifikan terhadap output rill. Selain itu, dalam jangka panjang pembiayaan syariah berpengaruh positif dan signifikan terhadap output riil di Indonesia. Lebih lanjut, Uji Kausalitas Granger membuktikan terjadinya kausalitas satu arah antara output riil dan inflasi.
\end{abstract}

Economica: Jurnal Ekonomi Islam - Volume 11, Nomor 2 (2020) 
Hadi Sasana, Deni Ramdani, and Ivo Novitaningtyas

Dengan demikian, perbankan syariah mampu mendorong output riil di Indonesia. Hasil penelitian ini menjadi bahan pertimbangan bagi para pemangku kepentingan dan pengambil kebijakan untuk lebih memperhatikan strategi dan kebijakan yang mendukung pertumbuhan ekonomi di Indonesia.

Kata Kunci: Perbankan Syariah; Deposito Syariah; Pembiayaan Syariah; Inflasi; PDB 
An Empirical Analysis of The Impact of Islamic Banking ...

\section{Introduction}

The financial sector has an important role in achieving economic growth. This sector becomes the locomotive for real sector growth through capital accumulation and technological innovation. This sector can mobilize funds from people with a surplus condition to those with a deficit of funds (Abduh, Brahim, and Oma 2012). This sector can also mobilize savings and provide borrowers with a variety of financial instruments with high quality and low risk (Bakar and Sulong 2018). These conditions can increase investment and accelerate economic growth.

One part of the financial sector is banking institutions. Therefore, banking institutions also have an important role in the economy, especially economic growth. Banking function in the economy consists of the functions of transmission, intermediation function, transformation, and distribution of risk function, and stabilization function (Simatupang 2019). As a transmission institution, banking institutions can control the amount of money and its circulation. As institution intermediation, banking institutions become the channel of funds from surplus units to deficit units. Finally, through the intermediation function, banking institutions can more effectively reallocate funds between two parties (surplus and deficit units). Therefore, through this function, banking institutions have a very important role in economic growth.

An effective and efficient bank intermediation function will support economic growth. The distribution of funds from surplus units and the availability of funds for deficit units indicate economic activity running. Furthermore, if these funds are invested in productive sectors that require financing, it can encourage economic growth. The relationship between investors and bank depositors that leads to investment will impact sustainable economic growth (Kassim 2016).

In Indonesia, the growth of banking institutions continues to increase, including Islamic banking. According to Pambuko \& Pramesti (2020), Islamic 
banking in Indonesia has a bright future as a part of the financial sector. This is because the majority of Indonesia's population is Muslim. The implementation of Islamic banking is carried out based on sharia principles which are regulated according to Islamic law. Sarwer et al. (2013) state that the Islamic financial system is more stable than the conventional financial system because it can eliminate debt financing. In addition, Islamic banks are considered to have less risk than conventional banks. Moreover, the development of Islamic banking in Indonesia continues to increase every year. The value of Islamic products and the development of Islamic banking in Indonesia over the last 10 years from 2007-2016 can be seen in Figure 1.

Islamic banking institutions apply the asset and production-based system reflected in mudharabah and musyarakah (Rama 2013; Fitri 2015). This financing pattern creates both the real sector and the financial sector to operate in a balanced way. As a result, the performance and contribution of Islamic banking are increasing along with the development of Islamic banking.

Figure 1. Development of islamic banking in indonesia

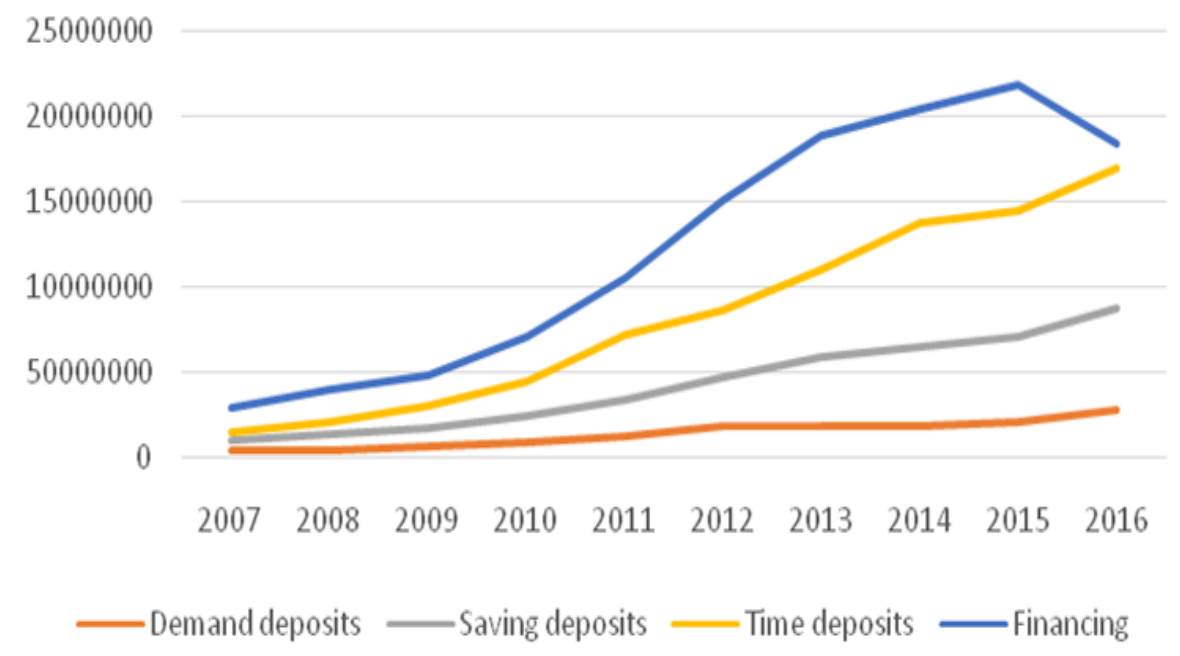


In addition, in their research, Adeel et al. (2015) state that financing in Islamic banking encourages economic growth in a country and capital accumulation.

The development of the collection and financing of third-party funds (accounts, savings, and time deposits) in Islamic banking in Indonesia continues to show a positive trend. At the same time, economic growth in Indonesia also shows a positive trend. As a result, positive trend-taking that occurs in the same relative time must influence each other. Therefore, this phenomenon needs to be studied whether the Islamic banking sector has influenced economic growth in Indonesia in the long term. If so, the two-way causality of the two also needs to be analyzed further..

\section{Literature review}

The relationship between financial sector development and economic growth is a topic of interest that needs to be further studied. Croitoru (2012) mentions the importance of the banking system and the growth of national income in economic development by identifying and financing the productive investment sector. According to Todaro \& Smith (2011) explains that to increase the growth rate, new investment is needed, so that the ratio of national saving and national income will determine the rate of economic growth. In addition, Solow's growth theory adds another factor in the equation model, namely labor, and introduces the third independent variable in the form of technology (Christianto Leasiwal 2013).

According to Arac and Ozcan (2014), there are three patterns of relationship between financial sector development and economic growth: supply-leading hypothesis, demand-following hypothesis, and bi-directional causality. The supply-leading hypothesis, first popularized by Schumpeter, states that the development of the financial sector plays an important role in stimulating economic growth. The financial sector's capability to encourage economic growth and the importance of the existence of financial institutions in the development of the economy. This hypothesis implied that the financial 
sector could create technological innovation to encourage economic growth. Furthermore, the development of the financial sector was considered capable of affecting the level of savings, investment, technological innovation, and long-term economic growth of a country.

Meanwhile, the demand-following hypothesis, popularized by Robinson, states that economic growth encourages the development of the financial sector (Carby et al. 2012). Therefore, the financial sector does not cause a causal impact on economic growth because the development of the financial sector following the economic growth leads to a rise in the demand for financial services. According to this hypothesis, as the economic growth created a rise in demand for financial services, the demand of the market activity for financing and credit increase. The study of Arac \& Ozcan (2014) explained a parallel relationship between economic growth and the financial sector in Turkey.

Finally, bi-directional causality is the hypothesis stating that the financial sector's development and economic growth are related or have a causality relationship. Many empirical studies of the relationship between financial sector development and economic growth have been conducted. For example, Abu-Bader \& Abu-Qarn (2008) prove the bi-directional causality relationship between Egypt's financial sector development and economic growth. Previously, Amiruddin (2007) finds that the development of the financial sector significantly caused economic growth in both the short term and long term in Malaysia. Those two findings prove to be supporting the bi-directional causality hypothesis. However, Dularif (2010) explains different results that the impact of the financial sector development did not encourage economic growth in Indonesia.

Meanwhile, in the context of Islamic finance, many empirical studies of the relationship between the Islamic financial sector and economic growth have also been conducted. For example, the research conducted by Tabash \& Dhankar (2013) about the Islamic financial system and economic growth in 
Bahrain. Their findings supported the hypothesis of bi-directional causality as Islamic financing proved to contribute to economic growth in the long term. Furthermore, Furqani \& Mulyani (2009), in their study about the contribution of Islamic banking to the Malaysian economy, find the existence of a significant relationship between economic growth and third-party funds collected by Islamic banking.

Moreover, Croitoru (2012) believes in the importance of keeping the existence between the banking system and national income growth in economic development by identifying and financing assistance to the productive investment sector. Previous studies have examined the financial sector's influence on Indonesia's economic growth based on the Vector Error Correction Model (VECM) (Inggrid 2006). However, the previous study uses different research variables to measure the development of the financial sector, such as the banking credit variable and the interest rate differential variable. Based on a review of the previous study, the difference between this study and previous studies is that this study focuses on the role of Islamic banking in actual output in Indonesia and uses different variables such as sharia deposits and financing.

\section{Methods}

This study used a quantitative approach. Secondary data of quarterly time series of 2007.1-2016.4 obtained from the International Monetary Funds (IMF), financial and economic statistics Indonesia (Statistik Ekonomi dan Keuangan Indonesia or called SEKI), Bank Indonesia, Islamic Banking Statistics (Statistik Perbankan Syariah or called SPS), and The Financial Services Authority (Otoritas Jasa Keuangan or called OJK) were used. Then, this study used four (4) variables. Variable Sharia Financing (Fin) and Sharia Deposits (Deps) were used as indicators of the development of the Islamic banking sector. Variable inflation (Inf) and Gross Domestic Product (GDP) based on constant prices of 2010 were used to describe the real sector 
economy. The data that has been collected was analyzed using Vector Error Correction Models (VECM) as a development model of VAR that considers the existence of not stationary data (Sinay 2014; Inggrid 2006). The basic model of VAR modified into the VECM model is shown as follows:

$$
\Delta X_{t}=\alpha_{i}+\sum_{i=1}^{k} A_{i} \Delta X_{t-i}+\sum_{i=1}^{k} B_{i} \theta_{t-i}+\mu_{t}
$$

Description:

$\Delta \quad$ : difference operator

Ai dan Bi : estimated parameter

$\mu \mathrm{t} \quad$ : error correction term

Moreover, the specification model of the Granger causality equation of VECM in this study is as follows:

$$
\begin{aligned}
& \begin{aligned}
\Delta L n G D P_{t}= & \alpha_{1}+\sum_{i=1}^{k} \beta_{1 i} \Delta L n G D P_{t-1}+\sum_{i=1}^{k} \gamma_{1 i} \Delta \operatorname{LnDeps}_{t-1}+\sum_{i=1}^{k} \delta_{1 i} \Delta \operatorname{LnFin}_{t-1}+\sum_{i=1}^{k} \theta_{1 i} \Delta I n f_{t-1} \\
& +\varphi_{1} E C T_{t-1}+\mu_{t}
\end{aligned}
\end{aligned}
$$

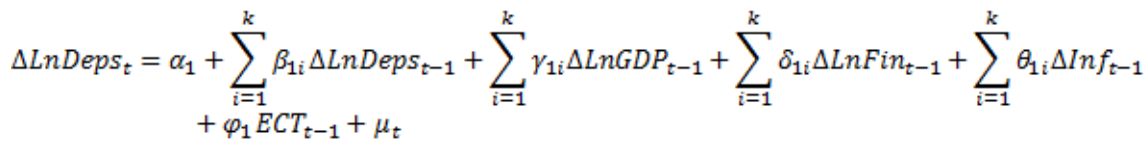

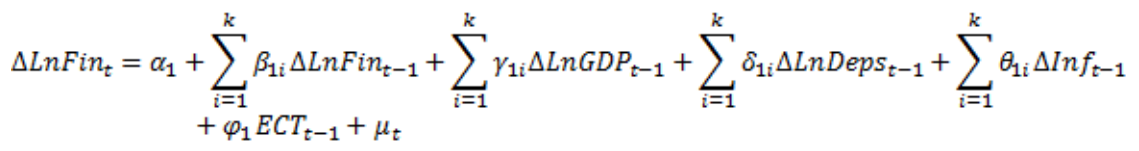

$$
\begin{aligned}
& \begin{array}{c}
\Delta I n f_{t}=\alpha_{1}+\sum_{i=1}^{k} \beta_{1 i} \Delta I n f_{t-1}+\sum_{i=1}^{k} \gamma_{1 i} \Delta L n G D P_{t-1}+\sum_{i=1}^{k} \delta_{1 i} \Delta L n D e p s_{t-1}+\sum_{i=1}^{k} \theta_{1 i} \Delta L n F i n_{t-1} \\
+\varphi_{1} E C T_{t-1}+\mu_{t}
\end{array}
\end{aligned}
$$


Where: Fin is Sharia financing, Deps is Sharia deposits, GDP is Gross Domestic Product based on constant prices of 2010, and Inf is inflation. $\Delta$ is the first difference, $k_{i}(\mathrm{i}=1.2)$ represents various lag on regresor, $\mathrm{ECT}_{\mathrm{t}-1}$ is the first lag value on error term of the integrated regression, and $\mu_{t}$ is an error term.

\section{Result and discussion}

The result of the test using Augmented Dickey-Fuller (ADF) on variables LGDP, LnDEPS, LnFIN, and stationary inflation at first differenceis summarized in Table 1.

The relationship among economic variables might create a deviation in the short term, but it will be normal in the long term using a balance mechanism. According to Houssain (2016), in dual system banking, low and stable inflation is important to keep sharia banking and monetary alive; otherwise, macroeconomic instability may thread competition of the monetary product of the sharia banking. Meanwhile, Johansen's cointegration test showed two co-integrated equations existed, as shown in Table 2.

Table 1. Augmented Dickey-Fuller (ADF) Unit Root Test

\begin{tabular}{lcc}
\hline Variable & Level, I(0) & 1 $^{\text {st }}$ Difference, I(1) \\
\hline LnGDP & -1.926261 & $-3.110871^{*}$ \\
LnDeps & -2.586544 & $-4.933997^{*}$ \\
LnFin & -2.820740 & $-4.551062^{*}$ \\
Inflation & -2.089266 & $-5.496259^{*}$ \\
\hline
\end{tabular}

The mark $\left.{ }^{*}\right)$ represent significance at $5 \%$.

Source : Data processed

Table 2. Johansen Co-integration Test

\begin{tabular}{ccccc}
\hline $\begin{array}{c}\text { Hypothesisthe number of } \\
\text { equations of co-integration }\end{array}$ & $\begin{array}{c}\text { Trace } \\
\text { statistic }\end{array}$ & $\begin{array}{c}\text { Critical } \\
\text { value }=\mathbf{0 , 0 5}\end{array}$ & $\begin{array}{c}\text { Max eigen } \\
\text { statistic }\end{array}$ & $\begin{array}{c}\text { Critical } \\
\text { value }=\mathbf{0 , 0 5}\end{array}$ \\
\hline $\mathbf{r}=\mathbf{0}^{*}$ & 84.86694 & 63.87610 & 35.12136 & 32.11832 \\
$\mathbf{r} \leq \mathbf{1}^{*}$ & 49.74557 & 42.91525 & 27.57552 & 25.82321 \\
$\mathbf{r} \leq \mathbf{2}$ & 22.17005 & 25.87211 & 17.66017 & 19.38704 \\
$\mathbf{r} \leq \mathbf{3}$ & 4.509881 & 12.51798 & 4.509881 & 12.51798 \\
\hline
\end{tabular}

The mark $(*)$ denotes a co-integrated rank.

Source: Data processed

Economica: Jurnal Ekonomi Islam - Volume 11, Nomor 2 (2020) 
Hadi Sasana, Deni Ramdani, and Ivo Novitaningtyas

Table 3. Granger Causality Test

\begin{tabular}{lcccc}
\hline \multirow{2}{*}{ Variable } & \multicolumn{4}{c}{ F- statistic \&probability () } \\
\cline { 2 - 5 } & LnGDP & LnDeps & LnFin & Inflation \\
\hline LnGDP & - & 0.32430 & 0.23903 & 6.63156 \\
& & $(0.8077)$ & $(0.8684)$ & $(0.0014)^{*}$ \\
LnDeps & 0.20538 & - & 0.96925 & 1.55590 \\
& $(0.8919)$ & & $(0.4201)$ & $(0.2206)$ \\
LnFin & 0.33298 & 0.45235 & - & 1.85966 \\
& $(0.8015)$ & $(0.7175)$ & & $(0.1578)$ \\
Inflation & 1.72583 & 0.57874 & 0.66982 & - \\
& $(0.1828)$ & $(0.6335)$ & $(0.5772)$ & \\
\hline
\end{tabular}

The mark $(*)$ represent significance at $5 \%$.

\section{Source: Data processed}

Moreover, the causality relationship resulted from the Granger Causality test shown in Table 3 shows one-way causality between actual output and inflation.

This finding showed that the growth of the actual output affected the inflation rate in Indonesia. This finding was in line with Lubis (2014) result that there is a one-way causality of the gross domestic product against the consumer price index. In contrast, a different result was proposed by Datta \& Mukhopadhyay (2011), who found a one-way causal relationship of inflation to economic growth based on the Malaysian case study. In addition, the finding of Gupta \& Singh (2016) confirmed that the existence of Johansen cointegration produces a single vector co-integration (long-term relationship) between FDI and GDP in India and China.

Furthermore, the Granger Causality test showed that a causal relationship did not occur between sharia banking and the real sector. This was understandable because the role of sharia banking has not been maximized yet in Indonesia's macroeconomic. Moreover, macroeconomic variables (the growth of GDP and inflation) significantly influence the stability of the monetary sector; therefore, low economic growth but high inflation affects the monetary stability of banks as its side effect (Männasoo and Mayes 2009). 
An Empirical Analysis of The Impact of Islamic Banking ...

Table 4. Estimation Result of Sharia Banking and Economic Growth

\begin{tabular}{|c|c|c|}
\hline & Variable & Coef. dan t statistic () \\
\hline \multirow[t]{12}{*}{ Short Term } & D(LNGDP $(-1))$ & $0.087133(0.47313)$ \\
\hline & D(LNGDP $(-2))$ & $0.294977(1.57160)$ \\
\hline & D(LNGDP $(-3))$ & $0.288052(1.65880)$ \\
\hline & D(LNDEPS $(-1))$ & $0.018484(1.95805)^{*}$ \\
\hline & $\mathrm{D}(\operatorname{LNDEPS}(-2))$ & $0.011190(1.54311)$ \\
\hline & D(LNDEPS $(-3))$ & $0.014877(2.04091)^{* *}$ \\
\hline & $\mathrm{D}(\operatorname{LNFIN}(-1))$ & $-0.002342(-0.39790)$ \\
\hline & D(LNFIN $(-2))$ & $-0.004305(-0.79357)$ \\
\hline & D(LNFIN $(-3))$ & $-0.007431(-1.54062)$ \\
\hline & D(INFLASI $(-1))$ & $3.01 \mathrm{E}-05 \quad(0.14643)$ \\
\hline & D(INFLASI $(-2))$ & $-0.000312(-1.46021)$ \\
\hline & D(INFLASI $(-3))$ & $-0.000524(-2.58441)^{* *}$ \\
\hline \multirow{6}{*}{ Long Term } & D(LNGDP $(-1))$ & 1.000 .000 \\
\hline & D(LNDEPS $(-1))$ & 0.000 .000 \\
\hline & $D(\operatorname{LNFIN}(-1))$ & $0.402373(4.80379)^{* * *}$ \\
\hline & D(INFLASI $(-1))$ & $-0.012782(-4.15509)^{* * *}$ \\
\hline & $\mathrm{R}^{2}$ & 0.678929 \\
\hline & F-statistic & 3.578518 \\
\hline
\end{tabular}

The mark $\left(*,{ }^{* *},{ }^{* *}\right)$ represents significance at $10 \%, 5 \%$, and $1 \%$ respectively

Source: Data processed

Furthermore, the estimation result of sharia banking's role to the real sector in Indonesia is shown in Table 4.

The values of the $t$ tables used in this research were 2.704, 2.021, and 1.684 , which were significant at a confidence level of $1 \%, 5 \%$, and $10 \%$, respectively.

The estimation result showed a short-term relationship between sharia banking and accurate Gross Domestic Product (GDP). In the short term, in Indonesia, sharia deposits in the first lag positively affected the actual output increase at $10 \%$ confidence with a coefficient of 0.018484 . This figure meant that when sharia deposits increased by $1 \%$, actual output increased by $0.02 \%$. The development of Sharia Bank and low inflation rate and exchange rate stability drove the development of actual output. Abduh etal. (2012) identified similarities between Sharia bank (total savings and total financing) and

Economica: Jurnal Ekonomi Islam - Volume 11, Nomor 2 (2020) 
economic growth in Bangladesh. Using co-integration and Granger Causality, Hasan \& Dridi (2012) concluded the positive relation between the two sectors both in the short and long term.

In the third lag, sharia deposits also positively and significantly affected actual output by a 5\% confidence level with a coefficient of 0.014877 . Therefore, when sharia deposits in the second lag increase by $1 \%$, the actual output in the current period will increase by 0.01 percent. Thus, Sharia system banks have been growing and successfully mobilizing additional resources for the financial sector to encourage the real sector (Beck, Demirgüç-Kunt, and Merrouche 2013). The economic growth resulting from the Sharia bank's asset escalation has been accepted as low risk cohered within Sharia bank was applied during financial global crashed.

In the long term, sharia financing had a positive effect on actual output in Indonesia. Sharia financing was identified had an impact on the increase of the real output at a confidence level of $1 \%$ with a coefficient of 0.402373 . This indicated that when sharia financing increased by $1 \%$, the actual output would also increase by $0.4 \%$. Therefore, sharia financing contributed to upliftreal output in Indonesia. This result was consistent with the conclusions suggested by Abduh et al. (2012) that financing provided by banks contributes to Indonesia's economic growth because the financial intermediation is running effectively in facilitating the transmission of the surplus funds to the deficit of funds. However, in the short term, the relationship between sharia financing and actual output was inconclusive. This result was also in accordance with Abduh et al. (2012) study, which showed that short-term sharia financing is not significantly related to economic growth in Bahrain. Conventional and Sharia banks have different approaches in the financial transaction, as sharia banks avoid unlawful aspects following Islamic law principles (El-Gamal 2006).

Another finding was that inflation affected actual output both in the short and long term in Indonesia. In the short term, inflation negatively affected 
actual output in the third lag with a confidence level of 5\% with a coefficient value of -0.000524 ; while, in the long run, inflation also negatively affected actual output at a $1 \%$ confidence level with a coefficient value of -0.012782 . A low and controllable inflation rate encouraged economic growth. This finding was in line with the result of the study of Najaf (2017) that explains a negative relationship between the inflation rate and the economic growth in Nigeria. Moreover, Shakhaowat (2015) also found a significant and negative relationship between inflation and long-term economic growth.

The results of this study give implications for the policymakers to emphasize promoting strategies and policies to support economic growth, such as promoting foreign investment, trade liberalization for services, and improving investment and trade climate to improve microeconomic stability. To achieve these goals, fiscal balance, trading balance, debt, exchange rate stabilization, and inflation should be controllable.

\section{Conclusion}

Based on the results and discussion of the influence of sharia bank on actual output in Indonesia, it could be concluded that in the short term, sharia deposit positively and significantly affects the actual output in Indonesia. Moreover, in the long term, sharia financing also has a positive and significant effect on actual output in Indonesia. Thus, Islamic banking effectively contributes to economic growth both in the short term and long term. In addition, the Granger Causality Test proves that there is one-way causality between actual output and inflation, which means that the growth of actual output affects the inflation rate in Indonesia. Furthermore, inflation has a negative effect on the real sector both in the short term and in the long term in Indonesia. This conclusion has implications for stakeholders and policymakers to pay more attention to strategies and policies that support economic growth. The limitation of this study is using secondary data from 2007-2016 and indicators used to measure research variables. Further

Economica: Jurnal Ekonomi Islam - Volume 11, Nomor 2 (2020) https://journal.walisongo.ac.id/index.php/economica 
studies can analyze data in the following period, add research variables or use other indicators to measure variables. Future research also needs to compare the impact of Islamic banking on economic growth in some countries or some regions in Indonesia to enrich the results and produce more comprehensive policy recommendations to the policymakers and stakeholders.

\section{References}

Abduh, Muhamad, Said Brahim, and Mohd Azmi Oma. 2012. "A Study on Finance-Growth Nexus in Dual Financial System Countries: Evidence from Bahrain." World Applied Sciences Journal 20 (8): 1166-74. https://doi.org/10.5829/idosi.wasj.2012.20.08.2027.

Abu-Bader, Suleiman, and Aamer S Abu-Qarn. 2008. "Financial Development and Economic Growth: Empirical Evidence from Six MENA Countries." Review of Development Economics 12 (4): 080414152145312-??? https://doi.org/10.1111/j.1467-9361.2008.00427.x.

Amiruddin, Rosilawati, Abu Hassan Shaari Mohd Nor, and Ismadi Ismail. 2007. "Test FOR Dynamic Relationship between Financial Development and Economic Growth in Malaysia: A Vector Error Correction Modeling Approach." Gadjah Mada International Journal of Business 9 (1): 61. https://doi.org/10.22146/gamaijb.5605.

Arac, Aysen, and Suleyman Kutalmis Ozcan. 2014. "The Causality Between Financial Development and Economic Growth: The Case of Turkey." Journal of Economic Cooperation and Development 35 (23): 171-98.

Bakar, Hamad Omar, and Zunaidah Sulong. 2018. "The Role of Financial Sector on Economic Growth: Theoretical and Empirical Literature Reviews Analysis." Journal of Global Economics 06 (04). https://doi.org/10.4172/2375-4389.1000309.

Beck, Thorsten, Asli Demirgüç-Kunt, and Ouarda Merrouche. 2013. "Islamic vs. Conventional Banking: Business Model, Efficiency and Stability." Journal of Banking \& Finance 37 (2): 433-47. https://doi.org/10.1016/j.jbankfin.2012.09.016.

Carby, Yanique, Roland Craigwell, Allan Wright, and Anthony Wood. 2012. "Finance and Growth Causality: A Test of the Patrick's Stage-of- 
Development Hypothesis." International Journal of Business and Social Science 3 (21).

Christianto Leasiwal, Teddy. 2013. "The Analysis Of Indonesia Economic Growth: A Study In Six Big Islands In Indonesia." Journal of Economics, Business, and Accountancy / Ventura 16 (1): 1-12. https://doi.org/10.14414/jebav.v16i1.121.

Datta, Kanchan, and Chandan Kumar Mukhopadhyay. 2011. "Relationship Between Inflation and Economic Growth in Malaysia: An Econometrics Review." International Conferences on Economics and Finance Research 4: 415-19.

Dularif, Muh. 2010. "Financial Development and Economic Growth: An Empirical Analysis of Indonesia." Jurnal BPPK 1 (4).

El-Gamal, M A. 2006. Islamic Finance Law,Economics, and Practice. Cambridge University Press.

Fitri, Maltuf. 2015. "Prinsip Kesyariahan Dalam Pembiayaan Syariah." Economica: Jurnal Ekonomi Islam 6 (1): 57-70. https://doi.org/10.21580/economica.2015.6.1.786.

Fritsch, Michael. 2017. "The Theory of Economic Development - An Inquiry into Profits, Capital, Credit, Interest, and the Business Cycle." Regional Studies $\quad 51 \quad$ (4): 654-55. https://doi.org/10.1080/00343404.2017.1278975.

Furqani, Hafaz, and Ratna Mulyani. 2009. "Islamic Banking and Economic Growth: Empirical Evidence from Malaysia." Journal of Economic Cooperation and Development, 59-74.

Gupta, Priya, and Archana Singh. 2016. "Causal Nexus between Foreign Direct Investment and Economic Growth: A Study of BRICS Nation Using VECM and Granger Causality Test." Journal of Advances in Management Research 13 (2): 179-202.

Hasan, Maher, And Jemma Dridi. 2011. "The Effects Of The Global Crisis On Islamic And Conventional Banks: A Comparative Study." Journal of International Commerce, Economics and Policy 02 (02): 163-200. https://doi.org/10.1142/S1793993311000270.

Hossain, Akhand Akhtar. 2016. "Inflationary Shocks and Real Output Growth in Nine Muslim-Majority Countries: Implications for Islamic Banking and 
Finance." Journal of Asian Economics 45 (August): 56-73. https://doi.org/10.1016/j.asieco.2016.06.004.

Inggrid. 2006. "Sektor Keuangan Dan Pertumbuhan Ekonomi Di Indonesia: Pendekatan Kausalitas Dalam Multivariate Vector Error Correction Model (Vecm)." Jurnal Manajemen Dan Wirausaha 8 (1): 40-50. https://doi.org/10.9744/jmk.8.1.pp.40-50.

Kassim, Salina. 2016. "Islamic Finance and Economic Growth: The Malaysian Experience." Global Finance Journal 30 (May): 66-76. https://doi.org/10.1016/j.gfj.2015.11.007.

Männasoo, Kadri, and David G Mayes. 2009. "Explaining Bank Distress in Eastern European Transition Economies." Journal of Banking \& Finance 33 (2): 244-53. https://doi.org/10.1016/j.jbankfin.2008.07.016.

Najaf, Rabia. 2017. "The Causal Relationship between Inflation and Economic Growth in Nigeria." Journal of Accounting \& Marketing 06 (01). https://doi.org/10.4172/2168-9601.1000208.

Pambuko, Zulfikar Bagus, and Diesyana Ajeng Pramesti. 2020. "The Effectiveness of Bank Aceh Syariah Conversion Decisions Diesyana Ajeng Pramesti." Economica: Jurnal Ekonomi Islam 11 (1): 1-23. https://doi.org/10.21580/economica.2020.11.1.3494.

Rama, Ali. 2013. "Perbankan Syariah Dan Pertumbuhan Ekonomi Indonesia." Signifikan: Jurnal Ilmu Ekonomi 2 (1). https://doi.org/10.15408/sjie.v2i1.2372.

Sarwer, M. Saleh, Muhammad Ramzan, and Waqar Ahmad. 2013. "Does Islamic Banking System Contributes to Economy Development." Global Journal of Management and Business Research 13 (2).

Shakhaowat Hossin, Md. 2015. "The Relationship Between Inflation and Economic Growth of Bangladesh: An Empirical Analysis from 1961 to 2013." International Journal of Economics, Finance and Management Sciences 3 (5): 426. https://doi.org/10.11648/j.ijefm.20150305.13.

Simatupang, H Bachtiar. 2019. "Peranan Perbankan Dalam Meningkatkan Perekonomian Indonesia." Jurnal Riset Akuntansi Multiparadigma 6 (2): 136-46. https://doi.org/10.30743/akutansi.v6i2.2184.

Sinay, Lexy Janzen. 2014. "Pendekatan Vector Error Correction Model Untuk Analisis Hubungan Inflasi, Bi Rate Dan Kurs Dolar Amerika Serikat." 
Barekeng: Jurnal Ilmu Matematika Dan Terapan 8 (2): 9-18. https://doi.org/10.30598/barekengvol8iss2pp9-18.

Tabash, M I, and Raj S Dhankar. 2013. "An Empirical Analysis of The Flow of Islamic Banking and Economic Growth in Bahrain." International Journal of Management Sciences and Business Research 1 (1): 96-103.

Todaro, Michael P, and Stephen C Smith. 2011. Economic Development. 11th ed. United States: Addison Wesley. 
Hadi Sasana, Deni Ramdani, and Ivo Novitaningtyas 